J. Clin. Chem. Clin. Biochem.

Vol. 28, 1990, pp. 407-411

(C) 1990 Walter de Gruyter \& Co. Berlin - New York

\title{
A Colorimetric Assay for the Determination of Acid Nucleoside Triphosphatase Activity
}

\author{
By M. Kirchgesser and N. Dahlmann \\ Institut für Klinische Biochemie der Universität Bonn
}

(Received February 26, 1990)

Summary: A photometric method for the determination of the acid nucleoside triphosphatase (EC 3.6.1. -) is described, in which inorganic phosphate is liberated from ATP or other nucleoside triphosphates. Colorimetric determination of liberated phosphate is based on the formation of a green complex of phosphomolybdate and malachite green hydrochloride. Optimal test conditions were evaluated as well as the sample preparation. The enzyme activities measured in 100 normal human sera are in the range of 0.5 to $9.0 \mathrm{U} / 1$ with an average of $4.0 \mathrm{U} / 1$ for men and $3.8 \mathrm{U} / 1$ for women.

\section{Introduction}

Recently we reported preliminary studies on a novel enzyme with an unusual $\mathrm{pH}$ optimum of 3.0 (1). This enzyme, acid nucleoside triphosphatase (EC 3.6.1.-), has been partly purified and characterised. The enzyme hydrolyses all nucleoside triphosphates only to their corresponding diphosphates and inorganic phosphate (2). Because of its putative lysosomal origin we have chosen myocardial infarction as a model of wound repair to investigate some aspects of its biological function. Enzymatic activity was maximally elevated six weeks after myocardial infarction (3), indicating that the enzyme did not originate from the myocardial tissue itself but probably from activated macrophages, which infiltrate the scar at that time (4).

The activity of the enzyme has so far only been measured by using radiolabeled nucleoside triphosphates as a substrate $(1,2)$, a method which is specific, but expensive and inconvenient for routine laboratory use. The assay presented here is based on a colorimetric determination of inorganic phosphate released by the acid nucleoside triphosphatase, using a sensitive method developed by Lanzetta et al. (5) and adapted to the actual assay conditions. In the present assay, phosphate forms a complex with ammonium molybdate and malachite green hydrochloride. The absorbance of the resulting green complex can be estimated at $640-660 \mathrm{~nm}$.

\section{Materials and Methods}

\section{Chemicals}

All tritium-labelled nucleotides were obtained from AmershamBuchler, unlabelled nucleotides from Boehringer-Mannheim. Malachite Green and dithiothreitol were purchased from Sigma Chemical Co., Rheomacrodex $10 \%$ was from Schiwa $\mathrm{GmbH}$, Glandorf. All other chemicals were supplied by E. Merck, Darmstadt, in the highest quality grade commercially available.

\section{Solutions}

Unless otherwise indicated distilled water was used in the preparation of all solutions.

Dialysis buffer: $150 \mathrm{mmol} / 1 \mathrm{NaCl}, 10 \mathrm{mmol} / \mathrm{l}$ Tris- $\mathrm{HCl} \mathrm{pH} 7.5$, Rheomacrodex $10 \%$, volume fraction 0.25 .

Reaction buffer: The following three stock solutions,

(l) $100 \mathrm{mmol} / \mathrm{l}$ citric acid $-\mathrm{NaOH}, \mathrm{pH} 3.0$,

(11) $40 \mathrm{mmol} / 1 \mathrm{EDTA}$, disodium salt,

(111) $40 \mathrm{mmol} / 1$ dithiotreitol,

were mixed in a ratio of $1+1+1$

Colour reagent: Mix one part of $42 \mathrm{~g} / \mathrm{l}$ ammonium molybdate in $4 \mathrm{~mol} / 1 \mathrm{HCl}$ with 3 parts of $0.45 \mathrm{~g} / 1$ Malachite Green, stir the mixture for at least $20 \mathrm{~min}$, then filter through a Whatman No. 5 filter paper. The ready-to-use reagent should not be stored for more than two weeks. 
Stabilizer: $340 \mathrm{~g} / 1$ sodium citrate.

Stop reagent: $250 \mathrm{~g} / 1$ trichloroacetic acid.

$P_{\mathrm{i}}$ standards: $\mathrm{Na}_{2} \mathrm{HPO}_{4}$ in the range $0-250 \mu \mathrm{mol} / \mathrm{l}(0-50$ $\mu \mathrm{mol} / 1$ final).

Substrate solution: Nucleoside triphosphate, $1.25 \mathrm{mmol} / 1$ (250 $\mu \mathrm{mol} / \mathrm{l}$ final). Store at $-20^{\circ} \mathrm{C}$.

Sample preparation: $250-500 \mu$ of serum are intensively dialysed for 12-24 hours in micro-collodion-bags (Sartorius $\mathrm{GmbH}$, Göttingen) at $4{ }^{\circ} \mathrm{C}$ against the dialysis buffer.

\section{Nucleoside triphosphatase test}

Samples and reagents are pipetted according to the scheme in table 1 . The total volume of the assay is $250 \mu$ l. After incubation for $30 \mathrm{~min}$ at $30^{\circ} \mathrm{C}$, stop reagent $(50 \mu \mathrm{l})$ is added, the mixture vortexed, then centrifuged for $3 \mathrm{~min}\left(8000 \mathrm{~min}^{-1}\right)$ to pellet the protein. Supernatant $(200 \mu \mathrm{l})$ is transferred to a new vial, followed by $1 \mathrm{ml}$ of colour reagent. After $1 \mathrm{~min}$ of colour development, $100 \mu \mathrm{l}$ of stabilizer are added and mixed thoroughly. Absorbance is determined at $650 \mathrm{~nm}$, using water as the blank. The colour is stable for at least 4 hours.

The substrate blank and the serum blank are both subtracted from the sample values and the resulting value is referred to the $P_{i}$ standard curve. One international unit $(U)$ represents the production of $1 \mu \mathrm{mol} \mathrm{P}_{\mathrm{i}}$ per minute.

\section{Radioisotopic nucleoside triphosphatase assay}

This assay, developed by Dahlmann et al. (1), uses radiolabeled nucleoside triphosphate as substrate. After incubation, nucleoside mono-, di- and triphosphates are separated by thin-layer chromatography, and radioactivity is measured by liquid scintillation counting.

\section{Results}

\section{Dialysis}

Because of the high $\mathrm{P}_{\mathrm{i}}$ concentration in human serum $(1-2 \mathrm{mmol} / \mathrm{l})$, this metabolite must be removed by dialysis to about $1 / 1000$ of the physiological concentration. In order to minimise volume changes of the samples during dialysis, an osmoticum should be added to the dialysis buffer. We chose a dextran solution in a final concentration of $2.5 \%$. This dialysis buffer has the average osmolarity of human serum. Serum blanks after extensive dialysis showed an absorbance $(\bar{x} \pm s)$ of $0.01 \pm 0.002$ making spot checks of 2 or 3 serum blanks sufficient for an entire series.

\section{Standard curves}

Since proteins in serum are capable of binding ions, we investigated the effect of serum protein on the recovery of inorganic phosphate. $P_{i}$ standards in a final concentration of $0-50 \mu \mathrm{mol} / 1$ were estimated in assay mixtures containing either buffer, serum, substrate, or combinations of these; there were no significant differences in $\mathrm{P}_{\mathrm{i}}$ recovery between them. Therefore, serum seems to have no matrix effect on $P_{i}$ recovery, and the $P_{i}$ standard curve can be determined in reaction buffer without the addition of protein. An absorbance of 1.0 corresponds to a $\mathrm{P}_{\mathrm{i}}$ concentration of $60-80 \mu \mathrm{mol} / 1$.

\section{Substrate stability}

To distinguish between enzymatic turnover and unspecific hydrolysis, the stability of different substrates was tested at various temperatures and $\mathrm{pH}$ values with a substrate concentration of $250 \mu \mathrm{mol} / \mathrm{l}$. For these experiments background values of the substrates were not subtracted. A non-enzymatic hydrolysis value of $5 \%$ corresponds to an absorbance of 0.15 . The stability of 2'-deoxythymine triphosphate (dTTP) was monitored at four different temperatures at $\mathrm{pH}$ 3.0. The maximal hydrolysis rate was found to be $0.5 \%$, measured over a period of 30 minutes at $37^{\circ} \mathrm{C}$, whereas at $0{ }^{\circ} \mathrm{C}$ no hydrolysis was observed (fig. 1). An incubation temperature of $30^{\circ} \mathrm{C}$ is a compromise between the optimal temperature of $43{ }^{\circ} \mathrm{C}$ for the enzymic activity (2) and a temperature that gives a low substrate blank value.

Since the assay is conducted at $\mathrm{pH} 3.0$ and stopped by the addition of trichloroacetic acid, the effect of $\mathrm{pH}$ on the substrate stability was assessed. The nonenzymatic hydrolysis rate of 2 '-deoxyadenosine triphosphate (dATP) and dTTP was measured at $\mathrm{pH}$ 1.0 and $\mathrm{pH} 3.0$ for $60 \mathrm{~min}$ at $30^{\circ} \mathrm{C}$ (fig. 2). The results indicate that, at $\mathrm{pH} 3.0$, both dTTP and dATP were stable with a rate of hydrolysis of less than $0.5 \%$ within one hour. However, the hydrolysis rate increased significantly at $\mathrm{pH} 1.0$ with a rate of $2 \%$ for dATP and 3\% for dTTP. Samples should therefore be kept on ice after the addition of stop reagent, and absorbance determined within 30 minutes.

Tab. 1. Pipetting scheme for nucleoside triphosphatase test (volumes in $\mu \mathrm{l}$ ).

\begin{tabular}{|c|c|c|c|c|c|}
\hline & Water blank & Substrate blank & Serum blanks & Samples (serum) & Standard curve \\
\hline Reaction buffer & 150 & 150 & 150 & 150 & 150 \\
\hline Water & 100 & 50 & 50 & - & 50 \\
\hline Serum & - & - & 50 & 50 & - \\
\hline Substrate solution & - & 50 & - & 50 & - \\
\hline $\mathrm{P}_{\mathrm{i}}$ standards & - & - & - & - & 50 \\
\hline
\end{tabular}




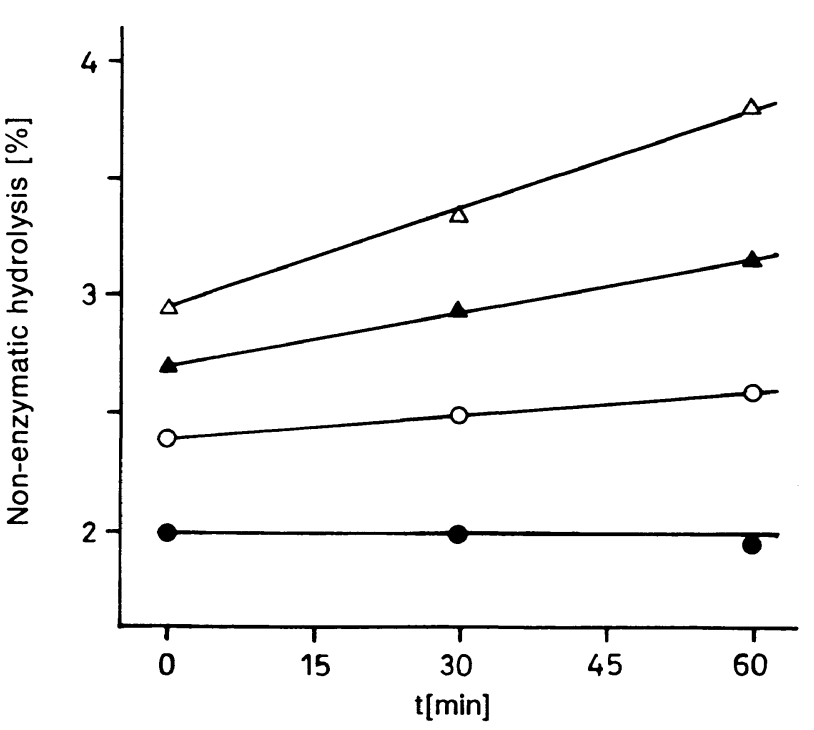

Fig. 1. Non-enzymatic hydrolysis of dTTP was measured for $60 \mathrm{~min}$ at $\mathrm{pH} 3.0$ and four different temperatures: $0^{\circ} \mathrm{C}$ $(\bullet), 20^{\circ} \mathrm{C}(0), 30^{\circ} \mathrm{C}(\Delta)$, and $37^{\circ} \mathrm{C}(\Delta)$.

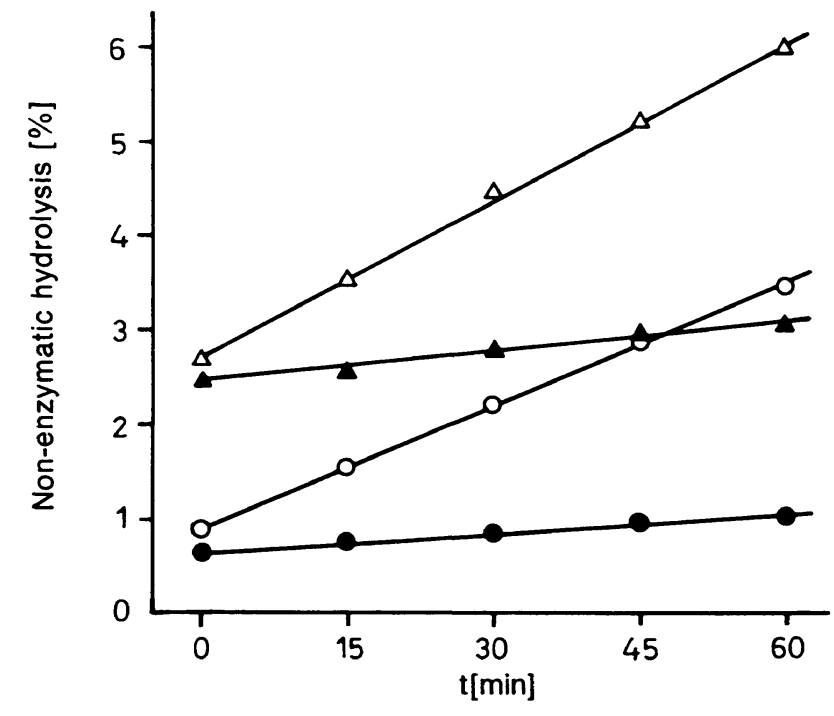

Fig. 2. Non-enzymatic hydrolysis of $\operatorname{dATP}(\bullet, 0)$ and $\operatorname{dTTP}$ $(\boldsymbol{\Delta}, \triangle)$ was measured at $\mathrm{pH} 3.0(\bullet, \Delta)$ and $\mathrm{pH} 1.0(\mathrm{O}$, $\triangle$ ) for $60 \mathrm{~min}$ at $30^{\circ} \mathrm{C}$.

Tab. 2. Non-enzymatic hydrolysis of different substrates $(250 \mu \mathrm{mol} / \mathrm{l})$ under standard assay conditions $\left(30 \mathrm{~min}\right.$ at $30{ }^{\circ} \mathrm{C}$ and $\mathrm{pH}$ 3.0)

\begin{tabular}{llllllll}
\hline Substrate & ATP & dATP & dTTP & dCTP & dGTP & dUTP \\
\hline Hydrolysis (\%) & 0.15 & 0.44 & 2.64 & 2.90 & 2.42 & 2.82 & \\
\hline
\end{tabular}

To compare the stability of different substrates, nonenzymatic hydrolysis was measured for $30 \mathrm{~min}$ at $30^{\circ} \mathrm{C}$ and $\mathrm{pH} 3.0$ at a final concentration of 250 $\mu \mathrm{mol} / 1$ of various nucleotides. Results are depicted in table 2 and indicate that ATP is about 3 times more

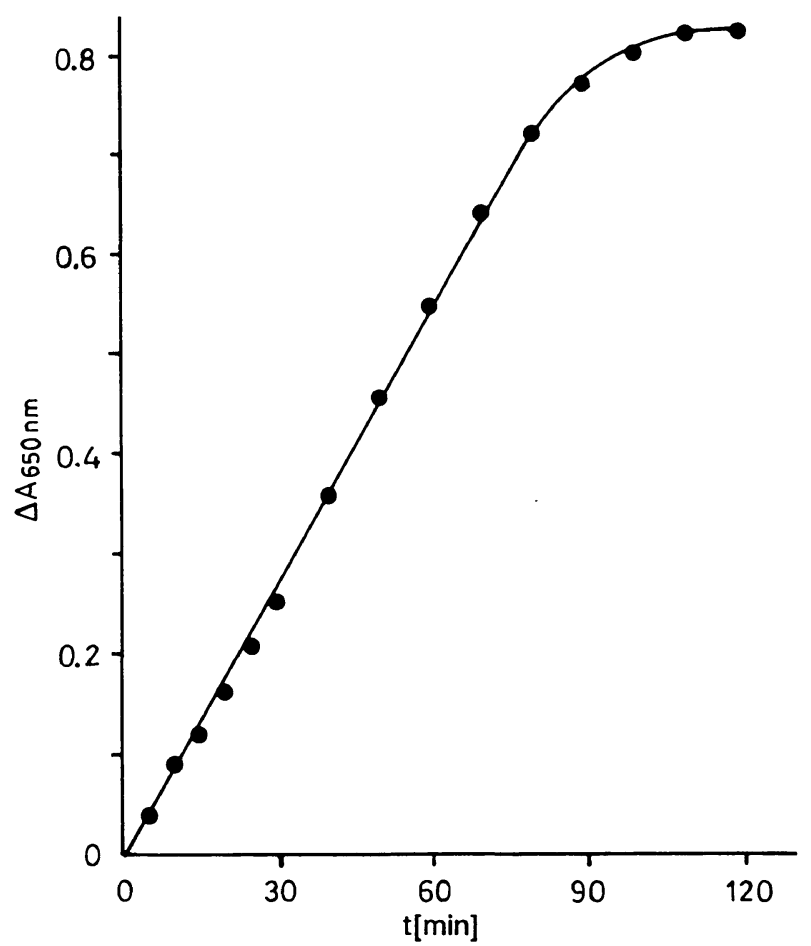

Fig. 3. Linearity of the assay at different incubation times. A pool of 20 sera was incubated with $250 \mu \mathrm{mol} / 1 \mathrm{dATP}$ at pH 3.0 and $30^{\circ} \mathrm{C}$. stable than dATP and 15 times more stable than all other deoxynucleotides. Therefore, we consider ATP to be the most suitable substrate. Although nucleotides can be stored at $-20^{\circ} \mathrm{C}$, repeated freezing and thawing increases the rate of non-enzymatic hydrolysis, making the inclusion of a substrate blank unavoidable.

\section{Substrate concentration}

As the substrate concentration is increased towards approximate saturation of the enzyme $\left(V_{\max }\right)$, the substrate blank increases faster than the sample values. It is therefore not possible to determine acid nucleoside triphosphatase activity at an optimal substrate concentration. At ATP concentrations up to 300 $\mu \mathrm{mol} / 1$, the substrate blank does not exceed an absorbance of 0.03 . A concentration of $250 \mu \mathrm{mol} / 1$ is recommended as an optimum. This is about 6 times more than the $K_{\mathrm{m}}$ value of ATP, sustaining a rate that is $85 \%$ of $\mathrm{V}_{\max }$.

\section{Time course of the reaction}

As the amount of substrate is the limiting factor of linearity, the time course was monitored at the substrate concentration of $250 \mu \mathrm{mol} / 1$ ATP. Under these conditions the change of absorbance remained linear for 90 minutes (fig. 3). 


\section{Linearity and sensitivity}

Under standard assay conditions the colorimetric assay was linear to an absorbance of at least 0.8 , and sensitive to about $0.3 \mu \mathrm{mol} / 1 \mathrm{P}_{\mathrm{i}}$. Sensitivity can be increased by changing the ratio of assay supernatant to colour reagent. Maximum sensitivity is achieved when $500 \mu \mathrm{l}$ of the supernatant are mixed with $1 \mathrm{ml}$ of colour reagent, but $200 \mu \mathrm{l}$ of supernatant are usually sufficient.

\section{Influence of anticoagulants}

Possible effects of anticoagulants on acid nucleoside triphosphatase activity were assessed under standard assay conditions. No significant differences were found for plasma containing heparin $(25000 \mathrm{U} / \mathrm{l})$, EDTA $(1 \mathrm{~g} / \mathrm{l})$, citrate $(7.6 \mathrm{~g} / \mathrm{l})$, fluoride $(2 \mathrm{~g} / \mathrm{l})$, or oxalate + fluoride $(3.4+3.4 \mathrm{~g} / 1)$ when compared with the untreated serum.

\section{Effect of storage}

Aliquots of a pool serum were stored at $-20,+4$ and $+20^{\circ} \mathrm{C}$. Acid nucleoside triphosphatase activity was determined over a period of 10 days. The data confirm that serum can be stored without loss of activity at $-20^{\circ} \mathrm{C},+4{ }^{\circ} \mathrm{C}$, or even room temperature for at least 8 days (data not shown).

\section{Precision}

Precision data are listed in table 3.

Tab. 3. Precision data of the assay $(n=20)$.

\begin{tabular}{|c|c|c|c|c|c|}
\hline \multicolumn{3}{|c|}{ Within-series precision } & \multicolumn{3}{|c|}{ Day-to-day precision } \\
\hline $\begin{array}{l}\text { Mean } \\
(\mathrm{U} / 1)\end{array}$ & $\begin{array}{l}\mathrm{SD} \\
(\mathrm{U} / \mathrm{l})\end{array}$ & $\begin{array}{l}\text { CV } \\
(\%)\end{array}$ & $\begin{array}{l}\text { Mean } \\
(\mathrm{U} / \mathrm{l})\end{array}$ & $\begin{array}{l}\mathrm{SD} \\
(\mathrm{U} / \mathrm{l})\end{array}$ & $\begin{array}{l}\text { CV } \\
(\%)\end{array}$ \\
\hline 1.28 & 0.033 & 2.6 & 0.64 & 0.025 & 3.8 \\
\hline 2.53 & 0.060 & 2.4 & 2.10 & 0.097 & 4.6 \\
\hline
\end{tabular}

Correlation between photometric and radioisotopic test

To evaluate the specificity of the present assay, acid nucleoside triphosphatase activity was determined in 50 sera of healthy blood donors, using the radioisotopic test as reference. Substrate concentration was $60 \mu \mathrm{mol} / 1 \mathrm{dTTP}$ according to $1 . \mathrm{c}$. (1). The correlation found between the two methods was excellent with a correlation coefficient of 0.97 (fig. 4).

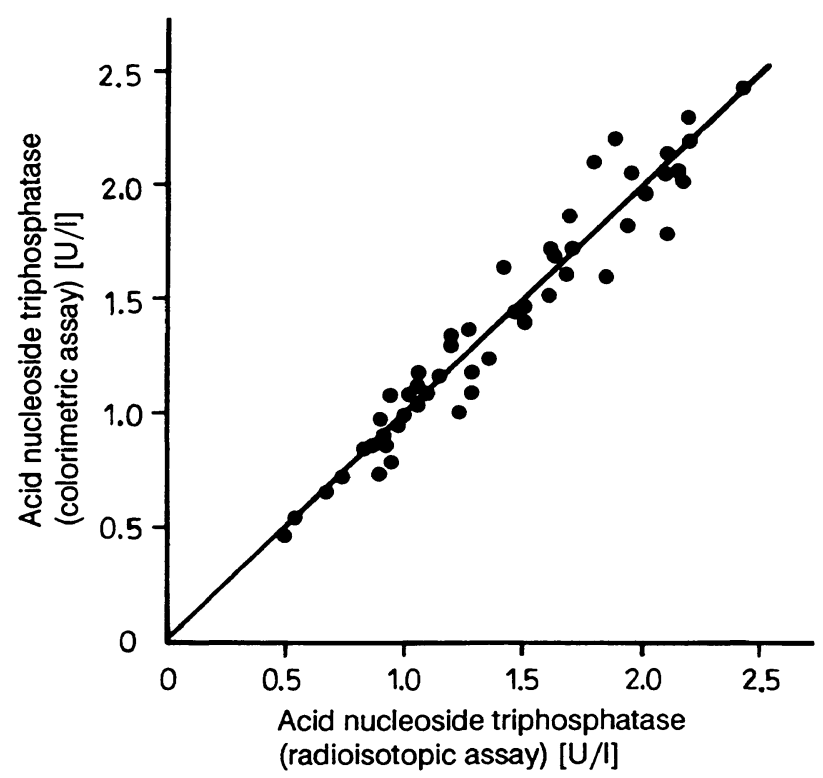

Fig. 4. Comparison of the catalytic activity of acid nucleoside triphosphatase as determined by the colorimetric and by the radioisotopic assay.

Reference values of nucleoside triphosph $\bar{c}$ tase

Nucleoside triphosphatase activity was determined in 100 sera of healthy blood donors (64 men, 36 women) under standard assay conditions with $250 \mu \mathrm{mol} / \mathrm{l}$ ATP as substrate. The mean \pm standard deviation was 4.0 $\pm 1.6 \mathrm{U} / 1$ for men, and $3.8 \pm 1.9 \mathrm{U} / 1$ for women

\section{Discussion}

In order to expand our knowledge of the clinical importance of acid nucleoside triphosphatase, a simple and rapid assay for a large number of patients' samples is required. Before the development of this photometric assay, the enzyme activity had only been measured using a radioisotopic assay involving thinlayer chromatography, which is time-consuming, expensive, and permitting only a few samples to be analysed simultaneously. However, it is easier to determine the enzymic production of inorganic phosphate. A number of methods $(6,7)$ as well as commercial kits were found unsuitable because of their low sensitivity, whereas the assay methods of Lanzetta (5) and Bencini $(8,9)$ are sensitive enough for the estimation of a $P_{i}$ concentration in the micromolar range. The method developed by Bencini, however, uses short wavelengths, and therefore the presence of proteins interferes with the assay. Other assay methods for determining inorganic phosphate are unsuitable if labile phosphate esters such as nucleoside triphosphates are present in high concentrations (10). 
The present photometric method is simple, economical and a large number of samples can be analysed within a few hours. Its specificity has been proved in comparison with the radioisotopic assay, which measures the specific reaction product, nucleoside diphosphate. Precision is excellent, with extensive linearity.

\section{References}

1. Dahlmann, N. \& Ueckermann, C. (1982) Properties of Four Different Deoxy-Thymidine-5'-Triphosphate Hydrolyzing Enzymes in Human Serum. Biochem. Int. 5, 185-192.

2. Dahlmann, N. \& Kirchgesser, M. (1990) Acid Nucleoside Triphosphatase: Partial Purification and Characterisation of a New Enzyme from Human Serum. Biochrem. Int. 20, $317-327$.

3. Dahlmann, N., Hobel, E. \& Steinhagen-Thiessen, E. (1985) A New Acid Nucleoside Triphosphatase as a Tool in Monitoring the Follow-up of Chronic Inflammation. European Society for Clinical Investigation, Toulouse p. 46.

4. Becker, A. E., Anderson, R. H. \& Braunwald, E. (1985) Cardiac Pathology, 1st edn., pp. 356-361, Thieme Verlag, Stuttgart.

5. Lanzetta, P. A., Alvarez, L. J., Reinach, P. S. \& Candia, O. A. (1979) An Improved Assay for Nanomole Amounts of Inorganic Phosphate. Anal. Biochem. 100, 95-97.

6. Berti, G., Fossati, P., Tarenghi, G. \& Musitelli, C. (1988) Enzymatic Colorimetric Method for the Determination of Inorganic Phosphorus in Serum and Urine. J. Clin. Chem. Clin. Biochem. 26, 399-404.

7. Van Zanten, A. P. \& Weber, J. A. (1987) Direct Kinetic Method for the Determination of Phosphate. J. Clin. Chem. Clin. Biochem. 25, 515-517.

8. Bencini, D. A., Shanley, M. S., Wild, J. R. \& O'Donovan, G. A. (1983) New Assay for Enzymatic Phosphate Release: Application to Aspartate Transcarbamylase and Other Enzymes. Anal. Biochem. 132, 259-264.

9. Bencini, D. A., Wild, J. R. \& Donovan, G. A. (1983) Assay of Inorganic Phosphate, Total Phosphate and Phosphatases. Anal. Biochem. 132, 254-258.

10. Ames, B. N. (1966) Assay of Inorganic Phosphate, Total Phosphate, and Phosphatases. Meth. Enzymol. VIII, pp. $115-118$.
Prof. Dr. N. Dahlmann

Institut für Klinische Biochemie

Sigmund-Freud-Straße 25

D-5300 Bonn 1 
